\title{
Analysis of the anti-racism law's efficacy, effectiveness and relevance from the view of legal professionals $^{1}$
}

\author{
Análise da eficácia, efetividade e relevância da lei antirracismo na \\ perspectiva dos profissionais do direito
}

\author{
Gislene Aparecida dos Santos ${ }^{2}$ \\ Universidade de São Paulo (São Paulo, SP, Brasil) \\ ORCID: https://orcid.org/0000-0003-4408-2119 \\ E-mail: gislene@usp.br
}

\begin{abstract}
Fernando Fagundes Ferreira ${ }^{3}$
Universidade de São Paulo (Ribeirão Preto, SP, Brasil) ORCID: https://orcid.org/0000-0001-9183-8287

E-mail: ferfff@usp.br
\end{abstract}

\section{Abstract}

This article aims to present and discuss the results of the Law and Racial Mediation research: The role and effectiveness of using law as a mediator for race relations in contemporary Brazil. We collected data and analyzed the point of view of legal professionals on the anti-racism law. Our sample, composed of 103 legal professionals, was non-probabilistic. The findings reveal that respondents, categorized as a group with a progressive vision within the law, have assessed that the anti-racism law is not efficient or effective. And they evaluated that the law should be improved. They show a predilection for non-punitive axes and for solutions that do not involve judicialization. They suggested restorative justice, the knowledge about discrimination and antidiscrimination; and development of skills to reduce the divergence between legal knowledge and the Brazilian reality.

1 SANTOS, Gislene Aparecida dos; FERREIRA, Fernando Fagundes. Analysis of the anti-racism law's efficacy, effectiveness and relevance from the view of legal professionals. Suprema: revista de estudos constitucionais, Brasília, v. 1, n. 1, p. 119-153, jan./jun. 2021.

${ }^{2}$ Associate Professor at the University of São Paulo. Professor of the Public Policy Management Course at School of Arts, Sciences and Humanities. Professor of the Graduate Program in Human Rights - Faculty of Law USP. Leader of GEPPIS - Group of Studies and Research of Public Policies for Social Inclusion and Coordinator of nPeriferias - Research Group on Peripheries - Institute of Advanced Studies of the University of São Paulo. She teaches and writes about human rights, post-colonial and decolonial studies, public policies and social inclusion, diversities, discrimination and racism. Gislene Santos is the author of books and articles among them the book "A Invenção do Ser Negro". Currículo Lattes: https://lattes.cnpq.br/2429128741364993.

${ }^{3}$ Associate professor at the University of São Paulo. Professor of Physics at University of São Paulo, campus of Ribeirão Preto. Professor of the graduate program on Complex Systems. Researcher at nPeriferias - Group of Research of the PeripheriesInstitute of Advanced Studies at the University of São Paulo. Currículo Lattes: https://lattes.cnpq.br/5515216429938578. 


\section{Keywords}

Racism; Anti-racism law; Law Quality; Legislative evaluation; Efficiency, Effectiveness of legislation.

\section{Contents}

1. Introduction. 2. The meaning of the evaluation of the law quality. 3. Method of data collection. 4. Data organization. 5. Data analysis: statistical analysis. 6. Findings. 6.1. Cronbach's alpha coefficient. 6.2. Response percentages. 6.3. Qualitative commentary. 7. Discussion. 8. Conclusion.

\section{Resuimo}

Este artigo tem como objetivo apresentar e discutir os resultados da pesquisa Lei e Mediação Racial: o papel e a eficácia da lei como mediadora das relações raciais no Brasil contemporâneo. Coletamos dados e analisamos a perspectiva dos profissionais do direito sobre a lei antirracismo. Nossa amostra, composta por 103 profissionais do direito, foi não probabilística. Os achados revelam que os entrevistados, categorizados como um grupo com uma visão progressista dentro do direito, avaliaram que a lei antirracismo não é eficiente ou eficaz. E avaliaram que a lei deveria ser aprimorada. Mostram predileção por vieses não punitivistas e por soluções que não envolvam judicialização. Eles sugeriram a justiça restaurativa, o conhecimento sobre discriminação e antidiscriminação e o desenvolvimento de habilidades para reduzir a divergência entre o conhecimento jurídico e a realidade brasileira.

\section{Palavras-chave}

Racismo; Lei antirracismo; Qualidade da Lei; Avaliação Legislativa; Eficiência, Eficácia da Legislação.

\section{Suimário}

1. Introdução. 2. O significado da avaliação da qualidade da lei. 3. Método de coleta de dados. 4. Organização dos dados. 5. Análise dos dados: análise estatística. 6. Resultados. 6.1. Coeficiente alfa de Cronbach. 6.2. Percentuais de resposta. 6.3. Comentário qualitativo. 7. Discussão. 8. Conclusão. 


\section{Introduction}

In Brazil, racism and racial discrimination is one of the most controversial themes. For a long time, the existence of discrimination based on race or color was denied, based on the idea of miscegenation would be insurance against the existence of racism.

In 1950, UNESCO sponsored studies in the country with the objective of investigating this phenomenon and ended by concluding that the great miscegenation in the country did not eliminate the building of racism. On the contrary, it constructed an ideology that hinders the perception of the existence of racial discrimination and racism. (CRUZ, 2014; MAIO, 1999, 2000). Since then, many studies have been done demonstrating that, in fact, racism has existed even before the official recognition of this phenomenon. Racism has shaping and structuring Brazilian society.

Despite that, racism and discrimination are still difficult to be admitted, in practice, in terms of intersubjective expectations, as well as, in structural and institutional spheres (SANTOS, 2015).

At the same time as the studies were growing, laws were created with the objective to protect the people against discrimination. Thus, in 1951 the Afonso Arinos Law was created (GRIN; MAIO, 2013), recognized as the first law to penalize (as a criminal offense) the practice of discrimination based on race or color. And, in 1989, in the wake of the reform of Brazil's federal constitution, Law 7.716/89 (or Lei Caó), was created which made racism a non-bailable crime. This law has been amended over the years. In 2010, a new legislation focused on the theme, has been created: the Statute of Racial Equality, Law 12.288/10 (SANTOS, 2012; SILVA JÚNIOR, 1998).

However, the existence of laws did not achieve a reduction in or punishment of racism. According to (FULLIN, 1999; GUIMARÃES, 1998; MACHADO; LIMA; NERIS, 2016; MATOS, 2016; SANTOS, 2015; SANTOS; NOGUTI; MATOS, 2014), most cases of racism that reached the criminal sphere had already been disqualified drawing attention to the reasons for this fact.

The reading of this phenomenon has been controversial. Some claim that the phenomenon of discrimination is difficult to measure and understand. (GRAYCAR, 2008; MOREIRA, 2017; PAGER, 2006; SALES JÚNIOR, 2006; SANTOS, 2018; SAPERSTEIN; KIZER; PENNER, 2016; SCHUCMAN; FACHIM, 2016) Others, that the judiciary would find it "difficult" to protect the rights of the black population. (ADORNO, 1995, 1996; ALVES, 2017; COSTA, 2016; MATOS, 2016; SANTOS, 2015; SANTOS; NOGUTI; MATOS, 2014; SANTOS, 2009, 2011, 2012). Not surprisingly, 
the study on the subject has spawned a complex line of investigation in the USA, which seeks to understand the interface between law, justice, and bias in the trails of cases involving persons from minority or vulnerable groups. (CRENSHAW, 2002, 2011; DELGADO; STEFANCIC, 2012; EDELMAN; SMYTH; RAHIM, 2016). And, also, resulted in the formation of lines of research in criminal law in Brazil. (DUARTE, 2002; FERREIRA; MACHADO, M. R. de A.; MACHADO, M. R., 2012; MACHADO, M. R. de A.; MACHADO, M. R., 2013; MOREIRA, 2017; RIOS, 2008; ROSS, 1996; SANTOS, 2001; ZAPATER, 2015; FULLIN; ZAPATER, 2016).

Laws that aim to curb discrimination are present in different countries of the world, they are not all necessarily in the criminal sphere, or aimed at punishment for discrimination exclusively by race or color. The existence of protective laws demonstrates that the subject crosses, in one way or another, different nations of the Globe. (MARTIN, 2015; PRIES; BEKASSOW, 2015; RAY; PRESTON, 2015).

This very controversial scenario about the understanding of racism as something that shapes the modern states (MILLS, 1999) led us to question the capability of the sphere of law to condemn racism and racial discrimination. Considering the existence of an anti-racism law, could we consider it sufficient to guarantee justice against the practices of racism? How to evaluate this law, its relevance and effectiveness?

Yet despite all the studies in the area, no rigorous evaluation of the quality of anti-racism law has been carried out to verify whether it would be a well-constructed law and what would be the impediments, if any, for it to gain quality.

This article aims to discuss the research findings ${ }^{4}$ conducted with legal professionals to analyze their perception of Law $7.716 / 89^{5}$.

We conducted an extensive survey with professionals who practice within different judiciary segments to understand how they evaluate the quality of the antiracism law, in a manner that gathered data that can be converted into guidelines indicative to a comprehensive assessment of this law.

We do not focus our research on their perception of the law's effectiveness in punishing racism through the assessment of tried cases or closed cases (see: SANTOS,

\footnotetext{
${ }^{4}$ Grant \#2015/23680-2, São Paulo Research Foundation (FAPESP).

${ }^{5}$ The investigation that resulted in findings presented in this article was done by Geppis - Group of Studies and Research of Public Policies for Social Inclusion. We want to thank: Amarílis Regina Costa da Silva, Bárbara Santos Araújo, Camila Matos, Gabriel Almeida Novais, Helton Hissao Noguti, Larissa Moura, Milena da Costa Edwirges, Nagila Camila Felix de Oliveira, Natali Lorraine Percídio da Silva: Geppis's team. Having talked to Professor Danilo Tavares da Silva and Professor Tiago André Vinicius dos Santos was essential to understand law vocabulary. Judge Marta Natalina Fedel also helped. Teresa Telles from Diversitas helped us to collected data from legal organizations. Without all those help it had been impossible to conclude this project.
} 
2015). Here we focus on the design of the law, it means, if in the perception of legal professionals, the way in which the law was drafted would allow the punishment of racism, or if the very existence of a punitive law focused on this issue would be considered a mistake, in their perspective.

For us, it was essential to conduct this investigation guided by what has been pointed out in the literature as to the important aspects to measure the quality of the legislation. Although our intention was not to carry out, in a strict sense, an evaluation of the anti-racism law, the knowledge built about law evaluation, as well as about racism in Brazil, helped us to build an instrument for collecting data which summed both the technical and social aspects required in talking about protection against racial discrimination.

Despite this research being an exploratory one, it can offer important information for the design of robust research on the subject and contribute to the outline of institutional legislative evaluations that deepen the issues raised here. Our informants were qualified and have been working in the field of law, the enforcers of the law, and its street level bureaucrats (LIPSKY, 1980). They were/are in a privileged position to provide information about the quality, scope, and relevance of the legislation to accomplish what was defined as their objective by the legislator.

This article is organized into eight parts. The first part is this Introduction. In the second, we discuss the meaning of quality law evaluation; in the third we present the method of data collection. The fourth part is dedicated to explaining data organization. In the fifth part we present statistical analysis using Cronbach's alpha coefficient that assures our sample has reliability in measuring what we intend to measure. In the sixth part we present our findings that were discussed in the seventh part. Finally, in the eighth part we present our conclusions.

\section{The meaning of the evaluation of the law's quality}

In Brazil, the evaluation of public policies and legislations is something extremely new when compared to what occurs in other countries. However, this argument cannot be a barrier to deny the importance of realizing legislations evaluation. It is essential to know how effective they are in order to fulfill what they were designed to accomplish.

In Brazil, the evaluation of public policies and/or legislation is something new compared to what happens in other countries (JANNUZZI, 2004, 2005, 2018). It is known that there is a tradition of evaluating the judiciary (OLIVEIRA; CUNHA, 
2020; SADEK, 2004). There is also a production on the impact of the legislature (MENEGUIN, 2010; MENEGUIN; SILVA, 2017). However, assessments of laws are less frequent in the country.

The evaluation of the quality of the law is highly debated outside of Brazil (MADER, 2001; MOUSMOUTI, 2012, 2014) where there is interest in making better laws and legislation. Thus, discussing what quality would mean and how to measure it has become something to be pursued considering the purpose of the legislation, the social context, policies, the viewpoint of different actors, and the different legal traditions (MOUSMOUTI, 2012, 2014). The author states that: "quality depends on both the process of rule-making as well as on the achievements and its real impact on society" (MOUSMOUTI, 2012, p.194).

On one hand, quality, essentially refers to the process, the content, the form as well as the impacts of the law and can thus be understood as a rational process of applying legal principles to make democratic decisions. On the other hand, quality essentially refers to the realworld outcomes of legislation and the degree of achievement of its goals; in other words, it refers to effectiveness. The concept of quality has essentially a dual nature and purpose both as rationality as well as effectiveness. (MOUSMOUTI, 2012, p.197)

The evaluation of legislation is fundamental for the legislators to have feedback about the acts they created, as well as, if the paths can be corrected if they are shown to be ineffective or, to understand the motives of the inefficiency or ineffectiveness of the legislation.

Mader does not distinguish the evaluation process from the public policy evaluation process. For him:

Evaluation means the analysis and assessment of the effects of legislation. This very general definition contains three elements. First, evaluation has to do with legislation, with normative acts and by implication, with the administrative decisions based on them. Formally its object therefore differs from that of policy analysis. However, at least where the rule of law is respected, there is not fundamental difference in practice between the evaluation of legislation and the evaluation of public policy. Second, evaluation is concerned with the causal relations between legislative actions and social reality. It is interested in the effects. It examines the extent and consequences of changes in attitude, behavior and circumstance that are potentially or actually due to legislative action. Third, evaluation tries to analyze and assess the effects of legislation in a methodical way. This analysis and assessment have three important characteristics. It is 
undertaken in a manner that can be generally understood and followed because it clearly identifies the bases for the statements or judgements about the potential or actual, causal connection between legislative enactments and the observable social reality. It is as systematic as possible; in that it considers all relevant effects. It is as objective as possible; in that it is not driven by particular interests". (MADER, 2001, p.123).

Therefore, quality of legislation should be an essential part of any proposed legislation, and, as in public policies, it must be part of the legislation cycle (for this, see: BOZZINI \& HUNT, 2015; FARIA, 2005; JANNUZZI, 2004, 2005, 2018).

In legal cases, according to Mader, this cycle would mean:

1 - the analysis and definition of the problem that legislative action presumes to solve. 2 - the determination or clarification of the goals of legislation. 3 - the examination of legal instruments or means that can be used to solve the problem and the choice of such instruments (basedamong other things-upon a prospective evaluation of their possible effects). 4 - the drafting of the normative content. 5 - the formal enactment. 6 the implementation. 7 - the retrospective evaluation; and 8 - if necessary or appropriate, the adaptation of legislation based on the retrospective evaluation. (MADER, 2001, p. 121).

Mader also considers it extremely important to not underestimate the political dimensions of the evaluation.

It strengthens the legislators' responsibility for the result of their decisions and thus improves the democratic functioning of the political institutions. It also creates the foundations for a critical - not only technocratic approach to legislation. As a matter of fact, elucidating the gap between legislative intentions and the results achieved may be an impetus to the adaptation of legal norms. It may also enhance critical examination of the political institutions. It would be wrong, therefore, to consider evaluation just as a tool of social engineering. Its critical function is as important as its technocratic function (MADER, 2001, p.131)

Considering legislative evaluation in the Brazil, different authors (SALINAS, 2008, 2013; SANDER, 1982, 1995; DAVOK, 2007; MENEGUIN, 2010; MENIGUIN; SILVA, 2017; MARINHO; FAÇANHA, 2000) help us to understand the importance of obtaining quality through a criterion of systematic evaluation.

Sander $(1982,1995)$ constructed a multidimensional evaluation model that can be utilized for us to think about quality assessment of anti-racism laws. According 
to the author, it is necessary to measure the efficacy (as an economic criterion that reveals the administrative capacity to produce the maximum results with the minimum resources); efficiency (institutional criterion that reveals the administrative capacity to attain the established goals and proposed results); effectivity (the political criterion that reflects the administrative capacity to satisfy the concrete demands from the external community) and the relevancy (the cultural criterion that measures the administrative performance in terms of importance, significance, pertinence and value considered in the improvement that it brings to the lives of individuals)

Although Sander $(1982,1995)$ was not focusing on legislative evaluation, the criteria of efficiency, efficacy, effectivity are frequent in the bibliography intended to assess the quality of the laws, as we have seen above. The relevance and effectiveness would possess political and cultural dimensions. The efficacy and efficiency would already have pedagogical and economical dimensions (in the case of the evaluation proposed by Sander (1982, 1995), but legal in the assessments we are proposing).

Evaluating quality will imply verifying if something has relevance and effectiveness (to know if it exhibits some value); if it has efficacy and efficiency (to evaluate if it possesses merit).If it does not have relevance, effectiveness, efficacy, and efficiency than it is not possible to affirm that something has any value from these parameters (DAVOK, 2007).

Salinas describes the process of creation, implementation, and evaluation of laws.

a) Identification and definition of the problem whose solution is attributed to legislative action. b) Determination of legislative objectives. c) Definition of the means potentially capable of generating the intended effects of the legislation and of various alternatives for solving the problem. d) prospective or ex-ante legislative assessment, consistent in investigating the capacity of the possible effects that are produced through legislation that are apt for achieving the stated or implied purpose of the legislation. e) choice of the medium or legislative solution that will be put to a vote. $\mathrm{f}$ ) implementation of law. g) Retrospective or ex-post legislative evaluation, consisting of an exam of the actual effects produced through legislation and comparing it with the stated or implicit objectives of the legislation. h) Adaptation, if necessary, of legislation based on legislative evaluation. (SALINAS, 2013, p. 234)

The author points out that, after concluding the steps that go from the identification of the problem to the implementation of the law, it becomes necessary to control the quality of the law already in place so that it can be identified if, in fact, it produced the intended effect by the legislator; whether the objectives have been fully 
or partly achieved; if they have produced other unintended effects and the causes of these effects (SALINAS, 2008, p. 34).

The legislative evaluation may address and analyze the effects of a law or its impact.

By effects, we mean only the consequences intended by the legislator, while the impacts represent all the subsequent consequences of applying legislation, even if not foreseen or intended by the person who formulated it. With regards to the effects of legislation, it can be evaluated on three specific criteria: the effectivity, the efficacy and efficiency. (SALINAS, 2013, p. 238)

Salinas (2008, p. 14) also considers that, if the ex-ante evaluation permits the creation of laws to function, the ex-post evaluation allows us to verify if this occurred and, if it has not occurred, and it also makes it possible to reconstitute the reasons that caused such unexpected consequences. Thus, we come to know "[...] to what point the legislation to be examined 'acts' in social life." (SALINAS, 2008, p. 21).

Mader (2001), however, emphasizes that the evaluation of law's efficacy is something remarkably interesting from the political point of view, since the objectives of the normative acts are politically "authorized" throughout the debate for implementation of a new law.

We are interested in discussing whether, from the perspective of law professionals, anti-racism law would present quality. It is important to state that we are calling anti-racism Law 7.716/89 whereby racism is classified as: "Crimes resulting from discrimination or prejudice of race, color, ethnicity, religion or national origin", it is understood that discrimination has its objective against an entire group, it is an imprescriptible and non-bailable crime; a public-order crime, causing harm and impeding the exercise of any right to a person. Our investigation will be concentrated on acts of discrimination that fall into the race or color category associated with black people (black or brown peoples).

Although large-scale legislative evaluations should be carried out by the legislative institutions themselves, the evaluations done through academic research as carried out by Salinas (2008, p. 49) - are fundamental in signaling the need for large-scale evaluations to be performed. The legislative evaluations can be carried out using a collection of data, archive analysis, case studies or experiments.

For this reason, we are encouraged to carry out this research in order to initiate a reflection on the importance of an in-depth assessment of the anti-racism law considering, in this case, how legal professionals understand the elements that constitute, or should constitute such a law. 


\section{Method of data collection}

The survey ${ }^{6}$ was conducted online using the platform Google Forms during the period from November 8, 2017 to April 3, 2018. The questionnaire contained five blocks with 26 principal questions subdivided into topics to which participants would have to respond. The responses had to follow the Likert model with five alternatives that varied in degrees of agreement or importance that they gave to the topics analyzed.

Our goal was not to conduct a strict opinion poll, but to collect the perceptions about how legal professionals evaluated Law 7.716/89 in various related issues to the professional profile of the respondents; about the quality and functionality of the law; the determining conditions for the crimes committed; about what is considered by those who must apply the law; the criminal justice system; the relevance of the law to alter behavior; the role of the victims and, finally, their understanding of discrimination and racism.

The research was disclosed using the following strategies:

a) We sent the survey to our personal network asking them to respond and to share the research; (snowball techniques and reaching strong networks).

b) We sent the survey by email and Facebook pages, to all the professional legal organizations in Brazil, whose names and addresses we got in the previous phase of the survey. They were municipal, state, federal organizations that aggregated lawyers, judges, attorneys, public defenders, prosecutors in a total of 153 organizations. Thus, the survey was sent to all of the emails and the Facebook pages of the organizations, requesting that they send the survey to all affiliates.

c) After that, we phoned them asking if they received our survey and if they had sent it to their affiliates.

All these procedures had the objective of guaranteeing that the survey reached strong and weak networks, and even people outside of our network. (GRANOVETTER, 1973; THIRY-CHERQUES, 2006; KLÜGER, 2017; ALVES; OLIVEIRA, 2018)7 .

It is important to emphasize that disclosure of the survey was not done through search tools offered by Facebook.

\footnotetext{
${ }^{6}$ For the original full survey take a look at this link: https://bit.ly/Memoria_Avaliacao_Lei7716_89

${ }^{7} \mathrm{~A}$ social network is made up of actors (nodes) and ties. Nodes are people connected by ties. Interpersonal ties can be of three types: strong (friends, families, people with whom we have close relationships), weak (acquaintances, people with whom we have more superficial relationships) or absent (people we do not know or do not relate to).
} 
We reached the scope below:

Table 1 - Reach of survey via Facebook

\begin{tabular}{c|c|c|c|c}
\hline Air time & $\begin{array}{c}\text { Persons } \\
\text { reached }\end{array}$ & $\begin{array}{c}\text { Link } \\
\text { Engagement }\end{array}$ & $\begin{array}{c}\text { Total } \\
\text { responses }\end{array}$ & $\begin{array}{c}\text { Responses from } \\
\text { legal practitioners }\end{array}$ \\
\hline 5 months & 1400 & 33 & 115 & 103 \\
\hline
\end{tabular}

Source: Created By the Authors.

Although this research was shared through Facebook, we did not use (in the specific case of legal professionals) paid tools for boosting outreach. This is because these tools sent the questionnaire randomly to different people identified by keywords that appeared on their Facebook profiles and the pages which with they interact. We wanted to only contact legal professional, for this, we considered that the best path would be direct communication with networks that bring these professionals together. The sample of this research was constructed in a non-probabilistic way, as was explained above.

\section{Data organization}

The questions were organized into five different blocks with the questions having the objective to investigate: Block 1 sample characterization which includes questions regarding occupational area, region of occupation, sex, color, gender. Block 2 Agreement with the Law's design ${ }^{8}$ having questions that allow us to evaluate the perception of technical topics referring to the quality of the law, such as, whether its object or purpose are clear, and if it is in concordance or divergence with the way the law was designed, if the foreseen punishments are adequate, or if there are other ways to curb new criminal practices through education of the condemned. Within this block we also asked about the conditions of affirming and proving the intent (ie the intention to commit the criminal act); about the best legal framework for judging racist conduct and about the best penal framework for racist conduct. This block, for the purposes of statistical analysis, was subdivided into four parts: the quality of the law, difficulties to prove the intention to offend, punishments provided by the law and the best legal framework 9 .

\footnotetext{
${ }^{8}$ We define as a designing of the law the way it was written, its objectives, objects, the legal scope where it was created. 
In Block 3 Professionals' profiles, we argued aspects that should be considered by those who judge and act in the judicial sphere, such as judges, prosecutors, lawyers, public defenders, police station head officer, during the time of the trial. We collected statements to map a profile of the respondents as being more or less progressive ${ }^{10}$ in terms of their professional practice in accordance with what they would consider more or less important for the same practice. In this sense, they should have expressed themselves on the value of being impartial, about discretionary, if they act in the terms of the law, considering the social value of their decisions, listening to the opinion of specialists in racism, considering only their standpoint not needing to justify decisions, their knowledge about discrimination and anti-discrimination. In addition, we inquired as to what they could consider acceptable as material evidence for the proof of a crime of racism, according to the law. And what victims should use to deal with their own cases.

We asked in Block 4 Knowledge about discrimination and racism regarding what would negatively or positively impact the application of anti-racism law, how could they resolve the problem of racism, what they thought about the use of the word race for the development of public policies and legislation, and if lawyers had knowledge about these questions. In this block, it is a matter of knowing how they perceived the theme of racism within the Brazilian reality facing a law, that could or not be well applied. They were asked about barriers that could be within the scope of the law itself, or in social, economic, or structural matters, or concerned to

\footnotetext{
to apply the law are well specified; whether the law covers all gaps for punishing discrimination; whether the solutions proposed by the Law tend to be implemented; whether the good protected by the law would already be protected by other existing laws causing confusion.

2 - About the punishments provided by the law: whether new practices of racism are prohibited; whether the condemned are educated by what the law provides as punishments; if the social damage can be repaired by what the law states; whether punishment should be provided by deprivation of liberty; whether fines should be the only punishments enforced; whether social provision, suspension or interdiction of rights should be the only punishments.

3 - What would be the best legal framework to deal with racism: Special Criminal Court; Civil court; Criminal Court; Restorative Justice; there should be a special criminal court to deal with these crimes; there should be no judicialization of this type of conduct. 4 - What would be the best penal framework to deal to racism: Racism and qualified injury should be equivalent crimes punished by the penal code as unspeakable crimes; Racism and qualified injury should be equivalent crimes punished by the penal code as crimes against honor; Racism and qualified injury must continue with different frameworks; Racism and qualified injury should not be included in any type of criminal law; Qualified injury should be framed, but racism should not.

5 - Reasons why it would be difficult to say that there is intention to offend (dolo): because racism involves unconscious aspects; because racism involves playful aspects; because people have no intention of offending; because people do not know what racism is; because crimes of racism overlap various forms of discrimination; it is entirely possible to prove the intention to discriminate in racist conduct.
}

${ }^{10} \mathrm{We}$ consider progressive, those professionals who have identified a greater tendency to accept that in the field of the judiciary, when dealing with racism, professionals should know about antidiscrimination, who have accepted that magistrates and prosecutors must justify their decisions, who have agreed to discretionary is not important, who have believed in the importance of the social value of decisions. 
miscegenation of the country as an argument against the very existence of racism in the country, or even about the behavior of the victims.

Finally, in Block 5 Summary of Law Assessment, we asked to evaluate the law stating whether they could consider it efficient, effective, relevant, if it should be revoked, improved, and assigning it a degree of importance. In all the blocks the respondents should have indicated their degree of agreement with the closed questions having five response options, that would go from totally agreeing to totally disagreeing, or extremely important to not being important. In the end, we left a field open for the respondents comment freely.

The amplitude of the questionnaire sought to obtain timely information that would allow us to understand the value that the respondents would give to the law, considering the various aspects related to it.

\section{Data analysis: statistical analysis}

We adopted the following steps for data processing:

a) Eliminating respondents who left questions unanswered.

b) Analyzing the consistency of responses by calculating Cronbach's alpha for each block.

c) Determining the blocks with Cronbach's alpha values> 0.6. If there was a block with a lower value, we divided it into smaller blocks so that each one had and alpha $>0.6$. We eliminated blocks with alpha $<0.6$.

d) Summarizing the data for each block according to the mean and median.

e) Summarizing the data according to the blocks using a Likert scale score measure defined in equation 2 below.

Cronbach's alpha coefficient provides a measure of internal reliability that, in general terms, is calculated based on the average scores of the correlations between items. Objectively, Cronbach's alpha coefficient helps to determine how much a block of questions (items) is measuring the same underlying concept. Thus, the greater the correlations between the items, the greater the alpha coefficient and the more likely a given block will be capturing the desired construct. In other words, there is more confidence that the answers given by respondents correctly measured what was asked to them in the blocks. In addition, higher alpha scores indicate that there is a lot of similarity in the response patterns in the chosen scale (Likert) when comparing 
respondents' answers. This is an indicator that there is an opinion that stands out in the multiple views collected here. This pattern is not a consensus, but a statistically significant intersection of agreement in the answers given.

Here we use the following expression (Figure1 - Equation 1) to obtain the alpha coefficient:

Figure 1 - Equation 1

$$
\alpha=\frac{k}{k-1}\left(1-\frac{\sum_{i=1}^{k} \sigma_{i}^{2}}{S_{T}^{2}}\right)
$$

Source: CRONBACH, 1951.

In this equation, the $\mathrm{k}$ value is the number of questions in each block, $\sigma_{i}^{2}$ is the variance of each question in a given block. Finally, $S_{T}^{2}$ is the total variance.

The Likert scale in this study has five items. Consider that we have $n$ people who answered the questionnaire. Consider that $n_{1}$ replied strongly disagree, $n_{2}$ partially disagree, $n_{3}$ neither disagree nor agree, $n_{4}$ partially agree and $n_{5}$ totally agree, such that $n_{1}+n_{2}+n_{3}+n_{4}+n_{5}=n$. The score will be defined as the following expression (Figure 2- Equation 2)

Figure 2 - Equation 2

$$
E=\frac{n_{1}+2 n_{2}+3 n_{3}+4 n_{4}+5 n_{5}}{n}
$$

Source: Created By the Authors.

We can define the width of the classification range as $\frac{5-1}{5}=0.8$. Therefore, we will classify the score obtained in each block, as follows: from 1 to 1.8 totally disagree, from 1.8 to 2.6 partially disagree, 2.6 to 3.4 neither disagree nor agree, from 3.4 to 4.2 partially agree and from 4.2 to 5 agree totally. 


\section{Findings}

\subsection{Cronbach's alpha coefficient}

Considering the Cronbach's alpha coefficient of the blocks as a whole, we noticed that there was a positive assessment, in general, of the reliability of the blocks that brought questions that indicated whether the law had been well designed, about the characterization of the professionals, and the block that asked about the importance of building some knowledge on racism, and also on the evaluation of the quality of the law. However, when we take a closer analysis, we can observe other aspects.

We divided block 2 originally proposed into four parts, as presented above. This was necessary to increase Cronbach's alpha coefficient.

Table 2 - Summary of Central Tendency and Reliability by Block

\begin{tabular}{|c|c|c|c|c|c|c|c|}
\hline \multirow[b]{2}{*}{ 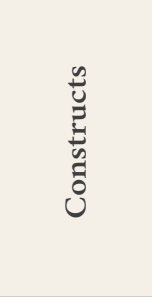 } & \multicolumn{4}{|c|}{ Agreement with the Law design } & \multirow[b]{2}{*}{$\begin{array}{c}\text { Block } 3 \\
\text { Professional } \\
\text { profile of } \\
\text { respondents }\end{array}$} & \multirow[b]{2}{*}{$\begin{array}{c}\text { Block } 4 \\
\text { Knowledge } \\
\text { about dis- } \\
\text { crimination } \\
\text { and racism }\end{array}$} & \multirow[b]{2}{*}{$\begin{array}{c}\text { Block } 5 \\
\text { Law } \\
\text { evaluation }\end{array}$} \\
\hline & $\begin{array}{c}\text { Block } 2 \\
\text { Law } \\
\text { quality }\end{array}$ & $\begin{array}{c}\text { Block } 2 \\
\text { Difficulties } \\
\text { to prove the } \\
\text { intention to } \\
\text { offend }\end{array}$ & $\begin{array}{c}\text { Block } 2 \\
\text { Punishments } \\
\text { provided by } \\
\text { the law }\end{array}$ & $\begin{array}{c}\text { Block } 2 \\
\text { Best legal } \\
\text { framework }\end{array}$ & & & \\
\hline Median & 3,5 & 2,5 & 2 & 3,5 & 4 & 4 & 4 \\
\hline Average & 3,14 & 2,5 & 2,2 & 3,0 & 3,8 & 3,56 & 3.34 \\
\hline $\begin{array}{l}\text { Alpha- } \\
\text { Cronbach }\end{array}$ & 0,65 & 0,64 & 0,65 & 0,2 & 0,75 & 0,62 & 0,38 \\
\hline
\end{tabular}

Source: Created By the Authors.

Comparing the average and the median, we observe that values for these measures of central tendency are close in each block. In general, respondents had a partial agreement in relation to blocks 3, 4 and 5. Regarding the block "Law quality" and "Best Legal Framework", the results point to a majority that neither disagree nor agree. In the case of "Difficulties to prove the intention to offend " and "Punishments provided for by law” it points to a position of partial disagreement. 
However, the issues related to the "Best Legal framework", taken as a whole, produced an exceptionally low value of Cronbach's alpha. The same happened with the "Law Evaluation" block with a summary of questions about how, in short, they evaluated the law.

The low value of Cronbach's alpha presented in the block "Law Evaluation" and in the block "Best Legal Framework" may be due to a low number of questions to measure the construct, low interrelationship between items or existences of other concepts within the same block. When this occurs, it is prudent to discard the block until there is a larger sample or new questions capable of measuring the target construct.

In block 5, evaluation of the law, the respondents only confirmed (in a more assertive way), what they had already reported in block 2 , and in hypothesis could account for a low Cronbach's alpha coefficient. In the subsection that inquires about the best legal framework, it is not possible to specify the exact reason for the low alpha. Nevertheless, the analysis of the percentage of responses given helps us to understand what was expressed by the Cronbach's alpha coefficient in this block and in other blocks.

\subsection{Response percentages}

The characteristics of the respondents are shown below (the values have been rounded down to the nearest decimal after the comma so the sum of the values shown below will not result in 100\%). 
Table 3 - Segment to which respondents belong

\begin{tabular}{l|c}
\hline SEGMENTS & $\%$ \\
\hline Lawyers & 33 \\
\hline Legal / Judiciary Assistant or advisor & 3.9 \\
\hline Judicial Center for Conflicts and Solutions & 1 \\
\hline Public Defender & 13.6 \\
\hline Police Station Head Officer & 1 \\
\hline Law Professors or Researchers & 21.4 \\
\hline Judicial Clerk & 1 \\
\hline Student & 2.9 \\
\hline Public Officials & 1 \\
\hline Magistracy & 13.6 \\
\hline Public Prosecutor (Ministério Público) & 2,9 \\
\hline Civil Registry Office & 1 \\
\hline Public Attorney (Procuradoria) & 3.9 \\
\hline Total & 100 \\
\hline
\end{tabular}

Source: Created By the Authors.

Table 4 - Color of respondents

\begin{tabular}{l|c}
\hline COLOR & $\%$ \\
\hline Yellow & 2 \\
\hline White & 62 \\
\hline Indigenous & 1 \\
\hline Non-Declared & 2 \\
\hline Brown & 16 \\
\hline Black & 17 \\
\hline Total & 100 \\
\hline
\end{tabular}

Source: Created By the Authors. 
Table 5 - Sex of respondents

\begin{tabular}{l|c}
\hline SEX & $\%$ \\
\hline Feminine & 45 \\
\hline Masculine & 54 \\
\hline Omission & 1 \\
\hline Total & 100 \\
\hline
\end{tabular}

Source: Created By the Authors.

Table 6 - Acting Region of respondents

\begin{tabular}{l|c}
\hline REGION & $\%$ \\
\hline West Central & 13 \\
\hline Northeast & 6 \\
\hline North & 2 \\
\hline Preferred not to answer & 1 \\
\hline Southeast & 55 \\
\hline South & 23 \\
\hline Total & 100 \\
\hline
\end{tabular}

Source: Created By the Authors.

The sample was comprised of a majority of white people (62\%) that work in the Southeast of Brazil (55\%) or the south (23\%). Black 17\%, Brown people corresponded to $16 \%$ of the sample. The difference between men and women is 9 percentage points. (54\% men and $45 \%$ women).

Considering the occupation, most of the respondents were part of the legal field (33\%), followed by professors and researchers of the area, who also graduated in law (21.4\%), magistrates were $13.6 \%$ of the sample. Public defenders were $13.6 \%$, Public ministers accounted for 2.9\%, District Attorneys were 3.9\%, legal/judicial advisor or assistant were $3.9 \%$, students (that act as trainees in law firms) were $2.9 \%$.

When we observed the response percentages given to individualized questions, it is possible to notice their indication towards paths for resolving the problem of racism, how they evaluate the law case by case and how they give suggestions for its betterment. 
For this, we extracted from the topics dealing with these themes, those which got a percentage above $50 \%$ (or the average) in degree of agreement/ importance or disagreement.

About the degrees of importance in regarding to the law, we observed that $38 \%$ of responders considered the law extremely important, and $27 \%$ considered it very important, and the other $27 \%$ considered it important. In this case, there were no indicatives superior to $38 \%$, but if we add the positive considerations, we can see that the law was well evaluated in terms of importance.

However, in respect to the evaluation of efficacy and effectiveness of the law, we observed that $84.4 \%{ }^{11}$ of the respondents asserted that the law should be strengthened. They disagreed, $79.6 \%{ }^{12}$ that it should be revoked.

There are high indices of divergence also surrounding the efficacy and effectiveness of the law. $67 \%{ }^{13}$ of respondents disagreed that the law is effective. Yet $57.3 \%{ }^{14}$ disagreed that it has efficacy. Yet, this last topic appears only in fourth place after consideration of $60.2 \%{ }^{15}$ of disagreement with the fact that the law would be relevant only to the black population.

It may seem contradictory that the law, in general, is considered important and, at the same time, is considered ineffective and irrelevant. However, studies on racism are fundamental in understanding this paradox. Considering the law's importance could be equivalent to assessing that it is fundamental in dealing with racism in the sphere of the law, but it also could mean that the anti-racism law fails to accomplish this mission. In our opinion respondents pointed to it in their answers.

We also evaluated whether respondents offered paths as to how the law could be changed.

We observed that respondents indicated that they agreed $81,5 \%{ }^{16}$ with the fact that the objective of anti-racism law is clear, that is, there would be no doubt about the law referencing punishment to crimes resulting from discrimination or prejudice of race, color, ethnicity, religion, or national origin.

\footnotetext{
${ }^{11} 55.3 \%$ said totally plus $29.1 \%$ said partially

${ }^{12} 66 \%$ said totally plus $13.6 \%$ said partially

${ }^{13} 40.8 \%$ saying partially plus $26.2 \%$ saying totally

${ }^{14} 34 \%$ saying partially plus $23.3 \%$ saying totally

${ }^{15} 20.4 \%$ saying partially plus $39.8 \%$ saying totally

${ }^{16} 41.7 \%$ saying totally plus $39.8 \%$ saying partially
} 
Responders also affirmed with $74.8 \%{ }^{17}$ agreement that the protection is clear and objective, not having, in this sense, doubts about the fact that the law has as a goal securing the principle of equality amongst all and curbing discrimination. Yet, $70.9 \%^{18}$ of them disagree, that the law covers all gaps to punish discrimination.

When it comes to criminal intention, $77.7 \%{ }^{19}$ of responders disagreed that people do not have the intention of offending. They also disagreed $-66 \%^{20}-$ that it is difficult to claim malice/ intention since there are humorous aspects involved in the practice of racism (some people affirm only the intent of making jokes without offensive implication). And lastly, they disagreed $-61.2 \%^{21}$ - that people are unaware of what is racism.

In terms of the punishment outlined by law, $75.7 \%{ }^{22}$ disagreed that the punishment helps repair the social harm or still, that it will educate the convicted person $\left(70.9 \%^{23}\right)$. However, respondents are even when it comes to responses given to an important topic, such as, whether or not legal punishment could curb new cases of racism. The disagreement came in at a little below $50 \%{ }^{24}$. That is, they define the law as having well established objects and objectives, yet they consider the law being unable to accomplish these goals since it cannot change behaviors.

Regarding the best legal framework for judging racist conduct, it can be observed that the responses are concentrated in turn on various scopes such as restorative justice and criminal court.

The responders quickly indicated a preference for restorative justice, with $68.9 \%^{25}$ in agreement. With a small margin of difference comes the criminal court, with $65.1 \%{ }^{26}$ agreement. The highest percentage is found in the disagreement with the fact that there should not be judicialization of racist conduct, $86.4 \%{ }^{27}$ of respondents affirm that position.

\footnotetext{
${ }^{17} 39.8 \%$ saying totally plus 35\% saying partially

${ }^{18} 40.8 \%$ saying totally plus $30.1 \%$ saying partially

${ }^{19} 51.5 \%$ saying totally plus $26.2 \%$ saying partially

${ }^{20} 45 \%$ totally and $21 \%$ partially

${ }^{21} 39.8 \%$ totally plus $21.4 \%$ partially

$2250.5 \%$ saying totally and $25.22 \%$ saying partially

${ }^{23} 42.7 \%$ saying totally and $28.2 \%$ saying partially

${ }^{24}$ They diverge also about establish fines or about stating deprivation of liberty as a better form of punishment.

${ }^{25} 33 \%$ saying totally plus $35.9 \%$ saying partially

${ }^{26} 27.2 \%$ saying totally and $37.9 \%$ saying partially

${ }^{27} 76.7 \%$ saying totally disagree and $9,7 \%$ saying partially disagree.
} 
We considered, also, to evaluate if the "color" factor would be a significant element in the provided responses about the legal framework to judge racist conduct.

Table 7 - The best legal framework to judge racist conduct by color

\begin{tabular}{l|c|c}
\hline \multicolumn{3}{c}{$\begin{array}{c}\text { INDICATE YOUR POSITION TO THE BEST LEGAL FRAMEWORK } \\
\text { TO JUDGE RACIST CONDUCT }\end{array}$} \\
\hline \multicolumn{2}{c}{ Median } \\
\hline Color & Criminal Court & Restorative Justice \\
\hline Yellow & 2,5 & 5 \\
\hline White & 4 & 4 \\
\hline Indigenous & 1 & 5 \\
\hline Mixed & 4 & 2,5 \\
\hline Black & 5 & 4,5 \\
\hline Not Declared & 3 & 4 \\
\hline Total & 4 & 5 \\
\hline
\end{tabular}

Source: Created By the Authors.

Evaluating the median of the answers given, it can be observed that the people who self-declared as black as having greater indication for the criminal courts. In all other groups, the median of responses in favor of restorative justice were higher.

We also observed the median behavior of the responses between different segments (taking into account the six segments with a greater number of responses). We evaluated that those who act as public attorney and with prosecution agree, on average, more with the criminal court system. Those who act as public defender, agree more with restorative justice. See table below. 
Table 8 - The best legal framework to judge racist conduct by professional occupations

\begin{tabular}{l|c|c}
\hline \multicolumn{1}{c}{ INDICATE YOUR POSITION TO THE BEST LEGAL FRAMEWORK } \\
TO JUDGE RACIST CONDUCT \\
\hline \multicolumn{1}{c}{ MEDIANA } \\
\hline Professional occupations & Criminal courts & Restorative justice \\
\hline Public Defender & 3.5 & 5 \\
\hline Legal Professional & 4 & 4 \\
\hline Public Prosecutor (Ministério Público) & 4 & 3 \\
\hline Law Professors or Researchers with \\
Training in Law
\end{tabular}

Source: Created By the Authors.

When it comes to themes dealing with the profile of legal professionals, all the responses presented fairly high progressive views. They indicate that having ample understanding of discrimination and anti-discrimination as being extremely important for judging cases of racism. 82.6\% of respondents considered that it is important that magistrates to have such knowledge. $81.5 \%$ that prosecutors should possess it. $81.5 \%$ that police station head officers should be aware of it, and $90.3 \%$ that lawyers and other public defenders should also have it.

Above this, responders only stressed impartiality as being extremely important for magistrates (87.4\%); prosecutors (69.9\%), police station head officers (86.4\%). Next, they consider that legal professionals should consider the social value of their decisions with $68.9 \%$ for magistrates, $70.9 \%$ for prosecutors, $74.7 \%$ for lawyers and public defenders and $68.9 \%$ for police station head officers. See the table below. 
Table 9 - Topic more important to face racial discrimination using the law

\begin{tabular}{|c|c|c|c|c|c|c|c|c|c|}
\hline \multirow{2}{*}{ Segments } & \multicolumn{3}{|c|}{ Impartiality } & \multicolumn{3}{|c|}{$\begin{array}{c}\text { Knowledge about } \\
\text { discrimination and anti-racism }\end{array}$} & \multicolumn{3}{|c|}{$\begin{array}{l}\text { Considering the social value of } \\
\text { their decisions }\end{array}$} \\
\hline & TOTAL & $\begin{array}{l}\text { Extremely } \\
\text { Important }\end{array}$ & $\begin{array}{c}\text { Very } \\
\text { Important }\end{array}$ & TOTAL & $\begin{array}{l}\text { Extremely } \\
\text { Important }\end{array}$ & $\begin{array}{c}\text { Very } \\
\text { Important }\end{array}$ & TOTAL & $\begin{array}{l}\text { Extremely } \\
\text { Important }\end{array}$ & $\begin{array}{c}\text { Very } \\
\text { Important }\end{array}$ \\
\hline Magistrates & $87,4 \%$ & $81,6 \%$ & $5,8 \%$ & $82,6 \%$ & $61,2 \%$ & $21,4 \%$ & $68,9 \%$ & $43,7 \%$ & $25,2 \%$ \\
\hline Prosecutors & $69,9 \%$ & $63,1 \%$ & $6,8 \%$ & $81,5 \%$ & $63,1 \%$ & $18,4 \%$ & $70,9 \%$ & $49,5 \%$ & $21,4 \%$ \\
\hline $\begin{array}{l}\text { Police } \\
\text { station head } \\
\text { officers }\end{array}$ & $86,4 \%$ & $76,7 \%$ & $9,7 \%$ & $81,5 \%$ & $66 \%$ & $15,5 \%$ & $68,9 \%$ & $53,4 \%$ & $15,5 \%$ \\
\hline $\begin{array}{l}\text { Lawyers } \\
\text { and Public } \\
\text { Defenders }\end{array}$ & & & & $90,3 \%$ & $76,7 \%$ & $13,6 \%$ & $74,7 \%$ & $56,3 \%$ & $18,4 \%$ \\
\hline
\end{tabular}

Source: Created By the Authors.

The respondents considered that lack of knowledge about anti-discrimination law and rights, $76.7 \%^{28}$, the lack of interest for these types of crime $74,7 \%^{29}$ and the divergence between judiciary knowledge and the Brazilian reality $74.8 \%^{30}$ as the main factors hindering or negatively impacting the application of the anti-racism law.

Therefore, in order to reverse this negative impact, it would be necessary to increase the knowledge about anti-discrimination rights, knowing the Brazilian society better, heighten the interest for studying about racial discrimination, and the last but not the least, forming legal professionals more progressives.

\footnotetext{
${ }^{28} 40.8 \%$ saying totally and $35.9 \%$ saying partially

${ }^{29} 41,7 \%$ saying totally and $33 \%$ saying partially

${ }^{30} 44.7 \%$ saying totally and $30.1 \%$ saying partially
} 
While these indicators converge towards the improvement of the antiracist law, the percentage of agreement on how the problem of racism could be solved points to non-judicial solutions, such as: education $99.1 \%^{31}$, public policies $91.3 \%{ }^{32}$; changing the political, economic, and social structures $72.8 \%{ }^{33}$.

\subsection{Qualitative commentary}

Our research also had a space where participants could leave their comments. We characterized the comments as: "Suggestions and critiques", "Compliments" and "General commentary".

On one hand, $50 \%$ of comments are suggestions and critiques. They dealt with the ways in which the research was constructed, suggestions about questions (the removal or addition of questions), they indicated having become confused about what the questions meant, they questioned the fact that other groups protected by law were not mentioned, they critiqued the fact that the research was conducted by "white people".

On the other hand, the compliments (14\% of received commentary) alternated between praising the research theme and the way the research was conducted.

Lastly, $36 \%$ of the comments brought general considerations about the theme that could not be read as critiques, suggestions, or praises. We consider this last group of comments to be the most interesting for the discussion.

Between those $36 \%$ of people who made general commentary, it is possible to observe two different response groups, those who critiqued the law and those who are in favor of it.

Those who critiqued the law emphasized in their commentary:

1 - strengthening education: they suggest education starting from the cradle.

2 - against the racial standard: they are against following the racial standard due to high miscegenation in Brazil.

3 - against politics of inclusion: they position themselves against quotas for black and mixed people, and against any politics focusing on race and color.

\footnotetext{
${ }^{31} 84.5 \%$ saying totally and $14.6 \%$ saying partially

${ }^{32} 68 \%$ saying totally and $23.3 \%$ saying partially

${ }^{33} 45.6 \%$ saying totally and $27.2 \%$ saying partially
} 
Those who were favorable to the law emphasized:

1 - impartiality: the need for suitable and impartial politics in respect to gender and race.

2 - the need for strict and strong laws

3 - resistance to the judiciary: seeing the law as operatively ineffective due to desired manipulation and lack of knowledge, racism, or for a lack of desire towards applying the law.

4 - punitive measures added with educational punishment for the defendant by way of community work with poor, black, quilombolas as a part of the sentence.

5 - consider structural racism.

6 - the law as insufficient, but necessary

7 - critique changes made to the law in the figure of racial injury.

\section{Discussion}

We observed that the respondents were quite favorable to the fact that the before and after analysis of the law as implemented could contribute to its efficacy and effectiveness. They indicated with $97.1 \%^{34}$ that agree with this assertion.

We affirm that the profile of the responders can be considered quite progressive, yet this cannot be generalized to all legal professionals since our sample was not fully random (despite the use of tools that allowed the survey to reach people throughout the country in a random way, combined with snowball and published to Facebook).

Attention is called, however, to the reduced number of responders belonging to the groups of black and mixed, expressively less than the responders who selfidentified as white. Despite the statute having been constructed with base in a crime against the Jewish community (LAFER, 2004), the complaints of racism are referred, in larger part, to black and mixed populations as is demonstrated by the study on dial racism. (MONTEIRO, 2003). The low percentage of individuals from these groups, who, in principle, are the most interested in the advancement in the quality of the law provides important data to be discussed.

${ }^{34} 50.5 \%$ saying totally plus $46.6 \%$ saying partially 
We came up with several hypotheses for the low participation of individuals from these groups departing from an analysis of the qualitative commentary. The first hypothesis is associated with the belief that an analysis of the quality of the law could result in, or signify, the contestation of conquered rights. When, in fact, we demonstrated that the analysis of the quality of the law and public policy seek to point out problems that potentially exist so that the law can fulfill what it sought out to do. Another hypothesis is associated with the disbelief that the judicial system can be altered or influenced by academic research.

In relation to the size of the sample we believe that it could be evidence of what was pointed out in the very responses given, that characterized the extent of the survey and, also, to the lack of concern for this type of crime. If there is no concern for this type of crime, there would be no reason to answer a survey with a vision of bettering the quality of law as it pertains to these types of crimes.

Although it is possible to see that the respondents did not believe that the laws could resolve the problem of racism, they presented suggestions of what could change its efficacy and efficiency which would be to implement restorative justice (since the law already exists within the penal system) and that legal professionals consider, in their professional conduct, impartiality, the social value of their decisions, knowledge about discrimination and anti-discrimination, and actions to reduce the divergence between judiciary knowledge and Brazilian reality.

These signs need to be carefully discussed to assess if they could be indications for a complete evaluation of the law and, also, for the implementation of complementary measures (public policies) with the objective of strengthening the law.

The theme of restorative justice has been discussed in different parts of the world as an alternative to incarceration and to punishment associated with traditional retributivejustice within the penalsystem. (ARMSTRONG, 2014;COSTA; MACHADO JÚNIOR, 2018; LATIMER; DOWDEN; MUISE, 2005; SANTANA; SANTOS, 2018; PATINO MARIACA; RUIZ GUTIERREZ, 2015; ROSSNER; BRUCE, 2018).

In fact, a discussion about mass incarceration (ALEXANDER, 2012; FERREIRA; MACHADO; MACHADO, 2012; MACHADO; MACHADO, 2013) makes us consider the options to this model as extremely important. Yet, when we confront challenge of the modus operandi of restorative justice we notice the enormous issues that need to be overcome. First, because it demands a high degree of exemption and impartiality 
from mediators, and, because literature points out the difficulties of the practice of restorative justice with cases involving markers of race, color, ethnicity, and gender. It is no wonder the themes of impartiality of the social status of decisions and the understanding of discrimination and anti-discrimination are emphasized alongside restorative justice in the provided responses.

\section{Conclusion}

We conclude that law professionals evaluate that the anti-racism law is not efficient, effective, or relevant. They evaluate that the law should be strengthened by way of measures that consider the social value of the decisions made by law professionals, knowledge about discrimination and anti-discrimination, and the implementation of restorative justice added to measures that bring together the knowledge of law professionals with the reality of Brazilian society.

These considerations can serve for the construction of indicators for public policy and for more robust evaluations turned to the judiciary sphere with the objective of strengthening, not only anti-racism laws, but other laws as well.

The study also revealed that white and black people do not share the same opinions when it comes to the implementation of restorative justice.

These assessments lead us to the questions; what is the significance and implementation of restorative justice in response to crimes of racism? Why did black participants manifest in opposition to these measures? In what ways is it possible to amplify the knowledge about discrimination and anti-discrimination? How can we analyze if law professionals are being impartial and if they have considered the social implications of their decisions? What can and what must the judiciary do to reduce the divide between knowledge created within this area and the social reality?

These are questions that need to be studied and that can be considered as indicators for new projects and investigations. 


\section{References}

ADORNO, Sérgio. Discriminação racial e justiça criminal em São Paulo. Revista Novos Estudos Cebrap, São Paulo, n. 43, p. 45-63, nov. 1995. Disponível em: https://novosestudos.com.br/wpcontent/uploads/2017/05/05_discriminacao_racial2.pdf.zip. Acesso em: 7 maio 2021.

ADORNO, Sérgio. Racismo, criminalidade violenta e justiça penal: réus brancos e negros e perspectiva comparativa. Estudos Históricos, v. 9, n. 18, p. 283-300, 1996. Disponível em: https://bibliotecadigital.fgv.br/ojs/index.php/reh/article/view/2034/1173. Acesso em: 7 maio 2021.

ALEXANDER, Michelle. The new Jim Crow: mass incarceration in the age of colorblindness. New York: The New York Press, 2012.

ALVES, Bruno Henrique; OLIVEIRA, Ely Francina Tannuri. Alguns conceitos da sociologia de Pierre Bourdieu relacionados com a análise de rede social. Informação \& Sociedade: Estudos, v. 28, n. 3, 2018. Disponível em: https://periodicos.ufpb.br/ojs/index.php/ies/article/ view/40892. Acesso em: 7 maio 2021.

ALVES, Dina. Rés negras, juízes brancos: uma análise da interseccionalidade de gênero, raça e classe na produção da punição em uma prisão paulistana. Revista CS, Cali, n. 21, p. 97-120, ene./ abr. 2017. Disponível em: https://doi.org/10.18046/recs.i21.2218. Acesso em: 5 ago. 2020.

ARMSTRONG, Jac. Rethinking the restorative-retributive dichotomy: is reconciliation possible? Contemporary Justice Review: Issues in Criminal, Social, and Restorative Justice, v. 17, n. 3, p. 362-374. Sep. 2014. Disponível em: https://doi.org/10.1080/10282580.2014.94 4796. Acesso em: 5 ago. 2020.

BOZZINI, Emanuela; HUNT, Jo. Bringing evaluation into the policy cycle. European Journal of Risk Regulation, v. 6, n. 1, p. 57-67, mar. 2015. Disponível em: https://doi.org/10.1017/ S1867299X00004281. Acesso em: 5 ago. 2020.

COSTA, Alexandre Emboaba da. Confounding anti-racism: mixture, racial democracy, and post-racial politics in Brazil. Critical Sociology, v. 42, n. 4-5, p. 495-513, 2016. Disponível em: https://doi.org/10.1177/0896920513508663. Acesso em: 5 ago. 2020.

COSTA, Daniela Carvalho Almeida da; MACHADO JÚNIOR, Elisio Augusto de Souza. Justiça restaurativa: um caminho possível na superação da racionalidade penal moderna?. Revista da Faculdade de Direito UFPR, Curitiba, PR, v. 63, n. 1, p. 65-91, maio 2018. Disponível em: https://revistas.ufpr.br/direito/article/view/54226. Acesso em: 5 ago. 2020.

CRENSHAW, Kimberlé. Twenty years of critical race theory: looking back to move forward. Connecticut Law Review, v. 43, n. 5, p. 1253-1352, jul. 2011. Disponível em: https://shain003. grads.digitalodu.com/blog/wp-content/uploads/2014/09/Twenty-Years-of-Critical-RaceTheory-Looking-Back-to-Move-Forward.pdf. Acesso em: 5 ago. 2020. 
CRENSHAW, Kimberlé. Documento para o encontro de especialistas em aspectos da discriminação racial relativos ao gênero. Revista Estudos Feministas, Florianópolis, v. 10, n. 1, p. 171, jan. 2002. Disponível em: https://periodicos.ufsc.br/index.php/ref/article/view/ S0104-026X2002000100011. Acesso em: 5 ago. 2020.

CRONBACH, Lee J. Coefficient alpha and the internal structure of tests. Psychometrika, v. 16, n. 3, p. 297-334, 1951.

CRUZ, Levy. Roger Bastide e a pesquisa da Unesco em São Paulo: introdução a uma crítica. Estudos de Sociologia, v. 2, n. 12, p. 69-95, abr. 2014. Disponível em: https://periodicos.ufpe. br/revistas/revsocio/article/view/235399. Acesso em: 5 ago. 2020.

DAVOK, Delsi Fries. Qualidade em educação. Avaliação, Campinas; Sorocaba, v. 12, n. 3, p. 505-513, set. 2007. Disponível em: https://www.scielo.br/pdf/aval/v12n3/a07v12n3.pdf. Acesso em: 5 ago. 2020.

DELGADO, Richard; STEFANCIC, Jean. Critical race theory: an introduction. New York: New York University Press, 2012.

DUARTE, Evandro Charles Piza. Criminologia e racismo. Curitiba: Juruá, 2002.

EDELMAN, Lauren B., SMYTH, Aaron C.; RAHIM, Asad. Legal discrimination: empirical sociolegal and critical race perspectives on antidiscrimination law. Annual Review of Law and Social Science, v. 12, p. 395-415, oct. 2016. Disponível em: https://doi.org/10.1146/ annurev-lawsocsci-110615-085234. Acesso em: 5 ago. 2020.

FARIA, Carlos Aurélio Pimenta de. A política da avaliação de políticas públicas. Revista Brasileira de Ciências Sociais, São Paulo, v. 20, n. 59, p. 97-110, out. 2005. Disponível em: https://doi.org/10.1590/S0102-69092005000300007. Acesso em: 26 abr. 2021.

FERREIRA, Luisa M. A.; MACHADO, Marta R. de A.; MACHADO, Maíra Rocha. Massacre do Carandiru: vinte anos sem responsabilização. Novos estudos CEBRAP, São Paulo, n. 94, p. 5-29, nov. 2012. Disponível em: https://www.scielo.br/scielo.php?script=sci_ arttext\&pid=S0101-33002012000300001\&lng=pt\&nrm=iso. Acesso em: 5 ago. 2020.

FULliN, Carmen. Criminalização do racismo: dilemas e perspectivas. Dissertação de Mestrado. Departamento de Sociologia da Universidade de São Paulo, USP, 1999.

FULLIN, Carmen; ZAPATER, Maíra. Apresentação: Dossiê direitos humanos e pesquisa em prisão no Brasil e na comunidade internacional. Aracê - Direitos Humanos em Revista, v. 3, n.4, p. 4-7, 2016. Disponível em: https://arace.emnuvens.com.br/arace/article/view/96/50. Acesso em: 8 maio 2021.

GRANOVETTER, Mark. The strength of weak ties. American Journal of Sociology, v. 78, n. 6, p. 1360-1380, 1973. Disponível em: www.jstor.org/stable/2776392. Acesso em: 10 ago. 2020. 
GRAYCAR, Reg. Gender, race, bias and perspective: or, how otherness colours your judgment. International Journal of the Legal Profession, v. 15, n. 1-2, p. 73-86, Nov. 2008. Disponível em: https://doi.org/10.1080/09695950802439734. Acesso em: 5 ago. 2020.

GRIN, Monica; MAIO, Marcos Chor. O antirracismo da ordem no pensamento de Afonso Arinos de Melo Franco. Topoi (Rio J.), Rio de Janeiro, v. 14, n. 26, p. 33-45, jun. 2013. Disponível em: https://www.scielo.br/scielo.php?script=sci_arttext\&pid=S2237-101X20130 00100033\&lng=en\&nrm=iso. Acesso em: 5 ago. 2020.

GUIMARÃES, Antônio Sérgio. Preconceito e discriminação: queixas de ofensa e tratamento desigual dos negros no Brasil. Salvador: Novos Toques, 1998.

JANNUZZI. Paulo de Martino. A importância da informação estatística para as políticas sociais no Brasil: breve reflexão sobre a experiência do passado para considerar no presente. Revista Brasileira de Estudos de População, São Paulo, v. 35, n. 1, e0055, 2018. Disponível em: https://www.scielo.br/scielo.php?pid=S0102-30982018000100551\&script=sci_arttext. Acesso em: 5 ago. 2020.

JANNUZZI, Paulo de Martino. Indicadores para diagnóstico, monitoramento e avaliação de programas sociais no Brasil. Revista do Serviço Público, v. 56, n. 2, p. 137-160, abr./jun. 2005.

JANNUZZI, Paulo de Martino. Indicadores sociais no Brasil: conceitos, fonte de dados e aplicações. Campinas: Alínea, 2004.

KLÜGER, Elisa. Espaço social e redes: contribuições metodológicas à sociologia das elites. Tempo Social, São Paulo, v. 29, n. 3, p. 83-110, dez. 2017. Disponível em: https://www. scielo.br/scielo.php? script $=$ sci_arttext\&pid=S0103-20702017000300083\&lng=en\&nrm $=$ iso. Acesso em: 10 ago. 2020.

LAFER, Celso. Parecer - o caso Ellwanger: anti-semitismo como crime da prática do racismo. Revista de Informação Legislativa, v. 41, n. 162, p. 53-89, abr./jun. 2004. Disponível em: https://www2.senado.leg.br/bdsf/item/id/948. Acesso em: 5 ago. 2020.

LATIMER, Jeff; DOWDEN, Craig.; MUISE, Daniele. The effectiveness of restorative justice practices: a meta-analysis. The Prison Journal, v. 85, n. 2, p. 127-144. Jun. 2005. Disponível em: https://doi.org/10.1177/003288550527696. Acesso em: 5 ago. 2020.

LIPSKY, Michael. Street-level bureaucracy: dilemmas of the individual in public services. New York: Russel Sage Foundation, 1980.

MACHADO, Marta Rodriguez de Assis.; LIMA, Márcia; NERIS, Natália. Racismo e insulto racial na sociedade brasileira: dinâmicas de reconhecimento e invisibilização a partir do Direito. Novos Estudos CEBRAP, São Paulo, v. 35, n. 3, p. 11-28, nov. 2016. Disponível em: https://www.scielo.br/scielo.php?script=sci_arttext\&pid=S0101-33002016000300011\&lng= en\&nrm=iso. Acesso em: 5 ago. 2020. 
MACHADO, Marta. Rodriguez de Assis; MACHADO, Maíra Rocha. O Direito Penal é capaz de conter a violência? In: SILVA, Felipe Gonçalves; RODRIGUEZ, José Rodrigo (org.). Manual de Sociologia Jurídica. 1.ed. São Paulo: Saraiva, 2013.

MADER, Luzius. Evaluating the effects: a contribution to the quality of legislation. Statute Law Review, v. 22, n. 2, p. 119-131, 2001. Disponível em: https://doi.org/10.1093/slr/22.2.119. Acesso em: 8 maio 2021.

MAIO, Marcos Chor. O Projeto Unesco: ciências sociais e o “credo racial brasileiro”. Revista USP, n. 46, p. 115-128, jun./ago. 2000. Disponível em: https://www.revistas.usp.br/revusp/ article/download/64014/66746/84216. Acesso em: 8 maio 2021.

MAIO, Marcos Chor. O Projeto Unesco e a agenda das ciências sociais no Brasil dos anos 40 e 50. Revista Brasileira de Ciências Sociais, São Paulo, v. 14, n. 41, p. 141-158, out. 1999. Disponível em: https://www.scielo.br/scielo.php?script=sci_arttext\&pid=S010269091999000300009\&lng=en\&nrm=iso. Acesso em: 5 ago. 2020.

MARINHO, Alexandre; FAÇANHA, Luís Otávio. Programas sociais: efetividade, eficiência e eficácia como dimensões operacionais de avaliação. Rio de Janeiro: IPEA, 2000. 22p. (Texto para discussão, 787). Disponível em: https://www.ipea.gov.br/portal/images/stories/PDFs/ TDs/td_0787.pdf. Acesso em: 5 ago. 2020.

MARTIN, Thomas. SOS racisme and the legacies of colonialism 2005-2009: an ambivalent relationship. Modern and Contemporary France, v. 23, n.1, p. 65-80, 2015. Disponível em: https://doi.org/10.1080/09639489.2014.968770. Acesso em: 5 ago. 2020.

MATOS, Camila Tavares de Moura Brasil. A percepção da injúria racial e racismo entre os operadores do direito. 2016. Dissertação (Mestrado em Diretos Humanos) - Faculdade de Direito, Universidade de São Paulo, São Paulo, 2016.

MENEGUIN, Fernando B. Avaliação de impacto legislativo no Brasil. Brasília: Senado Federal, Consultoria Legislativa, 2010.25p. (Textos para Discussão, 70). Disponível em: https:// www2.senado.leg.br/bdsf/bitstream/handle/id/182499/Texto70-FernandoMeneguin. pdf? sequence $=4 \&$ isAllowed $=y$. Acesso em: 8 maio 2021 .

MENEGUIN, Fernando B.; SILVA, Rafael Silveira (org.). Avaliação de impacto legislativo: cenários e perspectivas para sua aplicação. Brasília: Senado Federal, Coordenação de Edições Técnicas, 2017. 123 p. Disponível em: https://www2.senado. leg.br/bdsf/bitstream/handle/id/535244/avaliacao_de_impacto_legislativo_1ed.

pdf? sequence $=1 \&$ isAllowed $=y$. Acesso em: 10 maio 2021 .

MILLS, Charles. The racial contract. New York: Cornell University Press, 1999.

MONTEIRO, Fábio Dias. Retratos em branco e preto, retratos sem nenhuma cor: a experiência do Disque-Racismo da Secretaria de Segurança Pública do Estado do Rio de Janeiro. 2003. 186 f. Dissertação (Mestrado em Sociologia) - Universidade Federal do Rio de Janeiro, Rio de Janeiro, 2003. 
MOREIRA, Adilson José. O que é discriminação. Belo Horizonte: Letramento, Casa do Direito, Justificando, 2017.

MOUSMOUTI, Maria. Operationalising quality of legislation through the effectiveness test. Legisprudence, v. 6, n. 2, p. 191-205, 2012. Disponível em: https://doi. org/10.5235/175214612803596686. Acesso em: 8 maio 2021.

MOUSMOUTI, Maria. The "effectiveness test" as a tool for law reform. IALS Student Law Review, v. 2, n. 1, p. 4-8, 2014. Special Issue. Disponível em: https://journals.sas.ac.uk/ lawreview/article/view/2116/2047. Acesso em: 8 maio 2021.

OLIVEIRA, Fabiana Luci de; CUNHA, Luciana Gross. Os indicadores sobre o Judiciário brasileiro: limitações, desafios e o uso da tecnologia. Revista Direito GV, São Paulo, v. 16, n. 1, p. e1948, jun. 2020. Disponível em: https://bibliotecadigital.fgv.br/ojs/index.php/revdireitogv/ article/view/81688/77908. Acesso em: 11 ago. 2020.

PAGER, Devah. Medir a discriminação. Tempo Social, v. 18, n. 2, p. 65-88, 1 nov. 2006. Disponível em: https://doi.org/10.1590/S0103-20702006000200004. Acesso em: 5 ago. 2020.

PATINO MARIACA, Daniel Mauricio; RUIZ GUTIERREZ, Adriana Maria. La justicia restaurativa: un modelo comunitarista de resolución de conflictos. Revista de la Facultad de Derecho y Ciencias Políticas - Univ. Pontif. Bolivar, Medellín, v. 45, n. 122, p. 213255, Jan./Jun. 2015. Disponível em: https://www.scielo.org.co/scielo.php?script=sci_ arttext\&pid=S0120-38862015000100010\&lng=en\&nrm=iso. Acesso em: 5 ago. 2020

PRIES, Ludger; BEKASSOW, Natalia. Discriminação e racismo na União Europeia: diagnóstico de uma ameaça negligenciada e da investigação científica correspondente. Sociologias, Porto Alegre, v. 17, n. 40, p. 176-211, dez. 2015. Disponível em: https:// www.scielo.br/scielo.php? script $=$ sci_arttext $\&$ pid $=S 1517-45222015000300176 \& \operatorname{lng}=$ en $\& n r m=$ iso. Acesso em: 5 ago. 2020.

RAY, Brian; PRESTON, Valerie. Working with diversity: a geographical analysis of ethno-racial discrimination in Toronto. Urban Studies, v. 52, n. 8, p. 1505-1522, Jun. 2015. Disponível em: https://doi.org/10.1177/0042098014536628. Acesso em: 5 ago. 2020.

RIOS, Roger. Direito da antidiscriminação: discriminação direta, indireta e ações afirmativas. Porto Alegre: Editora Livraria do Advogado, 2008.

ROSS, Thomas. Just Stories: how the law embodies racism and bias. Boston, Massachusetts: Beacon Press, 1996.

ROSSNER Meredith; BRUCE, Jasmine. Trajectories and typologies of pre-sentence restorative justice rituals. Australian and New Zealand Journal of Criminology, v. 51, n. 5, p. 502-518, Dec. 2018. Disponível em: https://doi.org/10.1177/0004865817749263. Acesso em: 5 ago. 2020. 
SADEK, Maria Tereza. Judiciário: mudanças e reformas. Estudos Avançados, São Paulo, v. 18, n. 51, p. 79-101, maio/ago. 2004. Disponível em: https://doi.org/10.1590/S010340142004000200005. Acesso em: 11 ago. 2020.

SALES JÚNIOR, Ronaldo Laurentino de. Democracia racial: o não-dito racista. Tempo Social, São Paulo, v. 18, n. 2, p. 229-258, nov. 2006. Disponível em: https://www.scielo. br/scielo.php? script $=$ sci_arttext \&pid $=$ S0103-20702006000200012\&lng $=$ en $\& \mathrm{nrm}=$ iso.

Acesso em: 5 ago. 2020.

SALINAS, Natasha Schmitt Caccia. Avaliação legislativa no Brasil: um estudo de caso sobre as normas de controle das transferências voluntárias de recursos públicos para entidades do terceiro setor. 2008. 256 f. Dissertação (Mestrado em Filosofia e Teoria Geral do Direito) - Universidade de São Paulo, São Paulo, 2008. Disponível em: https://www. teses.usp.br/teses/disponiveis/2/2139/tde-31032009-153959/publico/Dissertacao_ Natasha_VF_2.pdf. Acesso em: 8 maio 2021.

SALINAS, Natasha Schmitt Caccia. Avaliação legislativa no Brasil: apontamentos para uma nova agenda de pesquisa sobre o modo de produção das leis. Revista Brasileira de Políticas Públicas, Brasília, v. 3, n. 2, p. 228-249, 2013. Disponível em: https://www. publicacoesacademicas.uniceub.br/RBPP/article/view/22199. Acesso em: 5 ago. 2020.

SANDER, Benno. Administração da educação no Brasil: é hora da relevância. Educação Brasileira, Brasília, v. 4, n. 9, p. 8-27, 1982.

SANDER, Benno. Gestão da educação na América Latina: construção e reconstrução do conhecimento. Campinas: Autores Associados, 1995.

SANTANA, Selma Pereira de; SANTOS, Carlos Alberto Miranda. A justiça restaurativa como alternativa à expansão penal e ao encarceramento em massa. Revista Brasileira de Políticas Públicas, v. 8, n. 1, 2018. Disponível em: https://doi.org/10.5102/rbpp. v8i1.5059. Acesso em: 5 ago. 2020.

SANTOS, Christiano Jorge. Crimes de preconceito e de discriminação: análise jurídicopenal da Lei n.7716/89 e aspectos correlatos. São Paulo: Ed. Max Limonad, 2001.

SANTOS, Elaine de Melo Lopes dos. Racismo e injúria racial sob a ótica do Tribunal de Justiça do Estado de São Paulo. São Carlos: UFSCar, 2011, 95f. Dissertação. (Mestrado em Sociologia). Universidade Federal de São Paulo.

SANTOS, Gislene Aparecida dos. Nem crime, nem castigo: o racismo na percepção do judiciário e das vítimas de atos de discriminação. Revista do Instituto de Estudos Brasileiros, n. 62, p. 184-207, dez. 2015. Disponível em: https://doi.org/10.11606/ issn.2316-901X.v0i62p184-207. Acesso em: 5 ago. 2020.

SANTOS, Gislene Aparecida dos. Raça e gênero: contribuições para pesquisas nas ciências sociais e jurídicas. Interfaces Brasil/Canada: Revista Brasileira de Estudos Canadenses, v. 18, n. 3, p. 42-77, 2018. Disponível em: https://periodicos.ufpel.edu.br/ojs2/index.php/ interfaces/article/view/14540. Acesso em: 5 ago. 2020. 
SANTOS, Gislene Aparecida dos; NOGUTI, Helton Hissao; MATOS, Camila T. de M. B. Racismo ou não?: a percepção de estudiosos do direito sobre casos com conteúdos racistas. Revista de Estudos Empíricos Em Direito, v. 1, n. 2, jul. 2014. Disponível em: https://doi. org/10.19092/reed.v1i2.355. Acesso em: 5 ago. 2020.

SANTOS, Marcio Henrique Casimiro Lopes Silva. Crime de racismo ou injuria qualificada?: tipificações e representações das ocorrências de práticas racistas entre os delegados de polícia de Campinas. 2009. 129 f. Dissertação (Mestrado [em Sociologia]) - Instituto de Filosofia e Ciências Humanas, Universidade Estadual de Campinas, Campinas, São Paulo, 2009. Disponível em: https://repositorio.unicamp.br/bitstream/REPOSIP/278843/1/Santos_ MarcioHenriqueCasimiroLopesSilva_M.pdf. Acesso em: 8 maio 2021.

SANTOS, Thiago Vinicius André dos. Racismo institucional e violação de direitos humanos no sistema de segurança pública: um estudo a partir do estatuto da igualdade racial. 2012, 219 f. Dissertação (Mestrado em Direito). Faculdade de Direito, Universidade de São Paulo, São Paulo, 2012. Disponível em: https://www.teses.usp.br/teses/ disponiveis/2/2140/tde-16052013-133222/publico/Dissertacao_Direito_TiagoVinicius_ VersaoRevisada.pdf. Acesso em: 8 maio 2021.

SAPERSTEIN, Aliya; KIZER, Jessica M.; PENNER, Andrew M. Making the most of multiple measures: disentangling the effects of different dimensions of race in survey research. American Behavioral Scientist, v. 60, n. 4, p. 519-537, 2016. Disponível em: https://doi. org/10.1177/0002764215613399. Acesso em: 5 ago. 2020.

SCHUCMAN, Lia Vainer; FACHIM, Felipe Luis. A cor de Amanda: identificações familiares, mestiçagem e classificações raciais brasileiras. Interfaces Brasil/Canada: Revista Brasileira de Estudos Canadenses, v. 16, n. 3, p. 182-205, 2016. Disponível em: https://periodicos.ufpel. edu.br/ojs2/index.php/interfaces/article/view/10001. Acesso em: 5 ago. 2020

SILVA JÚNIOR, Hédio. Anti-racismo: coletânea de Leis Brasileiras (federais, Estaduais e Municipais). São Paulo: Oliveira Mendes, 1998.

THIRY-CHERQUES, Hermano Roberto. Pierre Bourdieu: a teoria na prática. Revista de Administração Pública, Rio de Janeiro, v. 40, n. 1, p. 27-53, fev. 2006. Disponível em: https:// www.scielo.br/scielo.php?script=sci_arttext\&pid=S0034-76122006000100003\&lng=en\&nr m=iso. Acesso em: 10 ago. 2020.

ZAPATER, Maíra. O Haiti ainda é aqui: a lei 7716/89 e o 'racismo à brasileira'. Aracê - Direitos Humanos em Revista, v. 2, p. 156-173, maio 2015. Disponível em: https://arace.emnuvens. com.br/arace/article/view/29/28. Acesso em: 8 maio 2021. 


\section{Cited legislation}

BRASIL. [Constituição (1988)]. Constituição da República Federativa do Brasil de 1988. Brasília: Presidência da República, [2021]. Disponível em: https://www.planalto.gov.br/ ccivil_03/constituicao/constituicao.htm. Acesso em: 20 fev. 2021.

BRASIL. Lei no 1.390, de 3 de jullho de 1951. Inclui entre as contravenções penais a prática de atos resultantes de preconceitos de raça ou de côr. Brasília: Presidência da República, [1951]. Lei Afonso Arinos. Disponível em: https://www.planalto.gov.br/ccivil_03/LEIS/L1390.htm. Acesso em: 10 maio 2021.

BRASIL. Lei no 7.716, de 5 de janeiro de 1989. Define os crimes resultantes de preconceito de raça ou de cor. Brasília: Presidência da República, [2010]. Lei Caó. Disponível em: https:// www.planalto.gov.br/ccivil_03/leis/17716.htm. Acesso em: 10 maio 2021.

BRASIL. Lei no 12.288, de 20 de julho de 2010. Institui o Estatuto da Igualdade Racial; altera as Leis no 7.716, de 5 de janeiro de 1989, 9.029, de 13 de abril de 1995, 7.347, de 24 de julho de 1985, e 10.778, de 24 de novembro de 2003. Brasília: Presidência da República, 2010. Disponível em: https://www.planalto.gov.br/ccivil_03/_ato2007-2010/2010/lei/112288.htm. Acesso em: 10 maio 2021. 